\title{
Informal Mentoring at Work: A Review and Suggestions for Future Research
}

\author{
Suzanne Janssen, Mark van Vuuren and Menno D.T. de Jong \\ University of Twente, Faculty of Behavioral Sciences, Department of Communication Studies, PO Box 217, \\ 7500 AE Enschede, The Netherlands \\ Corresponding author email: s.janssen@utwente.nl
}

\begin{abstract}
This paper reviews the literature on informal mentoring at work. Based on two basic premises of interpersonal relationships, it discusses four promising areas in current mentoring research that could be cultivated further by future research. The first premise that we hold is that relationships never exist in a vacuum. Traditionally, however, mentoring literature has often overlooked the context of mentoring. We propose that the developmental network approach can be further extended to gather more insight into the interplay between mentoring dyads and their context. Also, mentoring literature could pay more attention to temporal influences in mentoring studies. The second premise that is applied is that relationships are not only instrumental in nature. However, mentoring research to date has mostly applied a one-sided and transactional view to mentoring. Relational mentoring theory could be helpful in examining relational motivations of both members. Also, mentoring literature can achieve more explanatory power by examining the underlying mechanisms of mentoring, next to social exchange principles, that cause these developmental changes. In summary, in each of these four research areas, we identify and discuss fundamental questions and developments in research that can advance mentoring theory and practice.
\end{abstract}

\section{Introduction}

How engagement in developmental relationships contributes to the growth and development of individuals is a question that has received much attention from vocational scholars. Typically, scholars have focused on the mentor-protégé dyad: 'a relationship between an older, more experienced mentor and a younger, less experienced protégé for the purpose of helping and developing the protégé's career' (Ragins and Kram 2007 , p. 5). Over the past 30 years, a large body of literature has emerged on a wide array of mentoring topics, including mentoring functions provided (Dickson et al. 2014; Kram 1985; Noe 1988; Ragins and McFarlin 1990; Scandura and Ragins 1993), career benefits associated with mentoring (Allen et al.

The authors sincerely thank IJMR Editor Oswald Jones, Associate Editor Sharon Mavin and the anonymous reviewers from $I J M R$ for their valuable comments on earlier drafts of this paper.
2004; Noe et al. 2002; Ragins and Cotton 1999), characteristics of successful mentoring programs (Allen et al. 2006a, Horvath et al. 2008; Underhill 2006) and negative experiences and behaviors (Burk and Eby 2010; Eby and McManus 2004; Feldman 1999).

That the field of mentoring research flourished in this way can be explained partly by its focused attention to specific elements of the mentoring concept. Mentoring literature is particularly strong in explaining how individual characteristics shape mentoring and predict mentoring outcomes (Chandler et al. 2011; Eby and Allen 2008; Jones and Corner 2012). However, it has also been criticized (e.g. Russell and Adams 1997) because of its empirically driven research, with little attention to theory building. With the strong focus on the outcomes of mentoring (Allen et al. 2008), other important aspects of mentoring have been overlooked. Mentoring research shows an 'impatience with troublesome conceptual and analytical problems' (Bozeman and Feeney 2007, p. 720), and tends to neglect more fundamental questions. 
We believe that two general premises on human relationships could contribute to a fuller understanding of such fundamental aspects of mentoring. First, one has to acknowledge the impact of relationships' environments on the ways in which people engage in and construct these relationships (Berscheid 1999; Blau 1964). Relationships do not exist in a vacuum. Individuals are embedded in different social networks that influence how each bond with others is formed and developed over time (e.g. Felmee 2001). Inspired by developmental network research, we argue that mentoring literature could pay more attention to the broader context of mentoring (e.g. Chandler et al. 2011; Jones and Corner 2012), including temporal influences. A second premise is that individuals not only engage in human relationships for instrumental purposes, that is, for positive outcomes for themselves. They also have relational or affiliative motives to form relationships. For example, Clark and Mills (1993) show that although sometimes people may follow social exchange norms and rules (e.g. giving benefits with the expectation of receiving comparable benefits in return), people can also follow communal norms (e.g. giving benefits in support of the partner's welfare without expecting benefits in return). However, as shown by relational mentoring theory (Ragins 2012; Ragins and Verbos 2007) mentoring literature has adopted a functional approach, resulting in the study of instrumental motivations to engage in mentoring relationships. Inspired by these insights from relational mentoring theory, we argue that the mentoring literature could pay more attention to the relational or affiliative motivations of both members.

This review has two goals. The first is to evaluate critically past mentoring research and explore aspects of our two premises of relationships that are relevant for theory development. This leads to four areas in the mentoring literature that could be advanced further: (1) the context of mentoring; (2) temporal influences on mentoring; (3) underlying developmental mechanisms of mentoring; and (4) relational motivations of mentors and protégés (see Table 1). In discussing these four areas, we identify promising research efforts that are critical for understanding mentoring, and we discuss how these efforts should be strengthened to cover the four areas more fully. Our second goal is to discuss the extent to which ongoing developments in research are able to contribute to a fuller understanding of these four areas of mentoring research. In our sections on future directions, we aim to show how insights from adjacent research areas (e.g. relationship science and leadership) could cultivate further our knowledge of mentoring.

\section{Boundary conditions}

Three boundary conditions should be taken into account when reading this review. First, this review focuses on informal mentoring relationships. These relationships differ from formal mentoring relationships on four dimensions (Baugh and Fagenson-Eland 2007). First, informal mentoring relationships are initiated by the members themselves and are most likely driven by the needs of both mentor and protégé, while formal mentoring relationships are matched by a third party to meet the organization's needs (Blake-Beard et al. 2007; Ragins and Cotton 1999). Second, informal mentoring relationships are seen as more intense than formal mentoring relationships, because the scope of informal relationships is unbounded, and the focus is not only on professional development, but also on personal development. According to Ragins and Cotton (1999), protégés with informal mentors receive more career development and psychosocial functions than protégés with formal mentors. However, this result was not confirmed in a later study by Allen and Eby (2004). Third, informal mentoring is not always recognized or articulated by both members and, as a result, is less visible than formal mentoring. Last, mentoring programs are constrained in their duration, while informal mentoring relationships are not.

A second boundary condition is that we did not focus on the influences of particular individual characteristics on mentoring. Individual attributes of participants in a mentoring relationship have been a major focus of researchers' attention (Chandler et al. 2011). From these studies, we learned that, in every mentoring relationship, the specific constellation of race, cultural background, gender and personality of the participants may influence the dynamics within that context. Acknowledging that all interactions are contextual accomplishments, these particular characteristics will not be the major focus of this review. Rather than the variance within dyads, we review the overarching themes that emerged in academic discussions about mentoring.

Third, a word on the conceptualization of 'relationships' is warranted. In contrast to the broad consensus that relationships are essential for humans, the range of perspectives on the nature of relationships and traditions of studying relationships is 
Table 1. Underdeveloped areas and current developments in informal mentoring literature

\begin{tabular}{|c|c|c|c|}
\hline $\begin{array}{l}\text { Underdeveloped areas } \\
\text { in literature }\end{array}$ & Key questions to address & Current developments & Future research directions \\
\hline \multicolumn{4}{|c|}{$\begin{array}{l}\text { Premise 1: Mentors and protégés are embedded in different social networks that influence how each bond with others is formed and } \\
\text { developed over time }\end{array}$} \\
\hline $\begin{array}{l}\text { The context of } \\
\text { mentoring }\end{array}$ & $\begin{array}{l}\text { What is the influence of other } \\
\text { people on protégés' } \\
\text { development? } \\
\text { How do mentoring relationships } \\
\text { and other work relationships } \\
\text { influence each other? } \\
\text { How do mentoring relationships } \\
\text { and their organizational context } \\
\text { influence each other? }\end{array}$ & $\begin{array}{l}\text { Developmental network research } \\
\text { Cotton et al. (2011); Cummings } \\
\text { and Higgins (2006); Higgins } \\
\text { (2000, 2001); Higgins and } \\
\text { Kram (2001); Higgins and } \\
\text { Thomas (2001); Higgins et al. } \\
\text { (2010); Kirchmeyer (2005); } \\
\text { Van Emmerik (2004) }\end{array}$ & $\begin{array}{l}\text { Seeing mentoring in its broader } \\
\text { context } \\
\text { Interplay between developmental } \\
\text { relationships } \\
\text { Multiplexity in developmental } \\
\text { networks } \\
\text { Content of dyads in } \\
\text { developmental networks } \\
\text { Interplay with the organizational } \\
\text { context }\end{array}$ \\
\hline $\begin{array}{l}\text { Temporal influences } \\
\text { on mentoring }\end{array}$ & $\begin{array}{l}\text { How do mentoring relationships } \\
\text { evolve over time? } \\
\text { How do long-term interpersonal } \\
\text { processes between mentors and } \\
\text { protégés evolve? } \\
\text { How does a mentoring history } \\
\text { influence one's current } \\
\text { mentoring relationships? }\end{array}$ & $\begin{array}{l}\text { Longitudinal approach to } \\
\text { mentoring } \\
\text { Blickle et al. (2009); Bouquillon } \\
\text { et al. (2005); Dobrow and } \\
\text { Higgins (2005); Donaldson } \\
\text { et al. (2000); Payne and } \\
\text { Huffman (2005); Singh et al. } \\
\text { (2009); Wang et al. (2009) }\end{array}$ & $\begin{array}{l}\text { A life cycle approach of } \\
\text { mentoring relationships } \\
\text { Influence of specific events on } \\
\text { the course of mentorships } \\
\text { Mentoring schema theory } \\
\text { (Ragins and Verbos 2007) }\end{array}$ \\
\hline \multicolumn{4}{|c|}{ Premise 2: Mentors and protégés have both instrumental and relational motives to form mentoring relationships } \\
\hline $\begin{array}{l}\text { Underlying } \\
\text { developmental } \\
\text { mechanisms of } \\
\text { mentoring }\end{array}$ & $\begin{array}{l}\text { What is the exact relationship } \\
\text { between mentoring processes } \\
\text { and positive outcomes? } \\
\text { What is the black box of } \\
\text { mentoring processes and } \\
\text { interactions? }\end{array}$ & $\begin{array}{l}\text { Mediating factors as explanation } \\
\text { Baranik et al. (2010); Pan et al. } \\
\quad \text { (2011) }\end{array}$ & $\begin{array}{l}\text { Uncovering developmental } \\
\text { mechanisms } \\
\text { Self-determination theory (Deci } \\
\text { and Ryan 2012) } \\
\text { Relational leadership theory } \\
\text { (Uhl-Bien 2006) }\end{array}$ \\
\hline $\begin{array}{l}\text { Relational motivations } \\
\text { of both mentors and } \\
\text { protégés }\end{array}$ & $\begin{array}{l}\text { How are mentors' and protégés' } \\
\text { relational motivations of } \\
\text { influence on their mentoring } \\
\text { relationships? } \\
\text { What are mentors' needs and } \\
\text { benefits? } \\
\text { What is the influence of dyadic } \\
\text { processes on mentoring? }\end{array}$ & $\begin{array}{l}\text { Relational mentoring theory } \\
\text { Fletcher and Ragins (2007); } \\
\text { Ragins (2011); Ragins and } \\
\text { Verbos (2007) }\end{array}$ & $\begin{array}{l}\text { Towards a balanced view on } \\
\text { mentoring } \\
\text { The need to belong as a } \\
\text { motivational factor } \\
\text { Mentors' needs } \\
\text { Mutuality processes in mentoring } \\
\text { relationships }\end{array}$ \\
\hline
\end{tabular}

bewildering. This range can be pictured as an example of the basic ontological distinction between realist entity approaches and constructionist process approaches of the world (Chia 1995; Van de Ven and Poole 2005). Taking an entity view means treating the world as a stable material substance, in which fixed things can be studied through causal models with independent and dependent variables. A process approach stresses the flux of life as a starting point, preferring the use of verbs rather than nouns for describing the ever-evolving emerging of organizing. Within organization and management studies, the tension between these approaches and their respective critiques are addressed regularly for impor- tant areas, including change (Hernes and Weik 2007; Tsoukas and Chia 2002; Weik 2011), internationalization (Welch and Paavilainen-Mäntymäki 2014), leadership (Cunliffe and Eriksen 2011; Uhl-Bien 2006), learning (Cunliffe 2008) and strategy (Sminia 2009). In mentoring studies, this division is almost completely absent in favor of the entity approach (see Jones and Corner (2012) for an exception). We refrain from reiterating the value of a more processoriented approach throughout the review, and confine ourselves to the work that is actually done. In the conclusion section, we suggest ways in which the process approach could enrich mentoring studies in the future. 


\section{Method of review}

We adopted a broad approach when searching papers for review. We used 'mentor*' as our primary broad search string, and identified sources within the following databases: PSYCINFO; Scopus; and Web of Science. We retained papers by their relevance as indicated by title or abstract, or by examination of the paper. In order to identify papers potentially missed, manual searches of key journals in the field of workplace mentoring (Academy of Management Journal, Academy of Management Review, Career Development International, Group \& Organization Management, Journal of Applied Psychology, Journal of Management, Journal of Organizational Behavior, Journal of Vocational Behavior and Personnel Psychology) were conducted. We also conducted manual searches of reference lists to identify additional relevant papers and handbooks (e.g. Handbook of Mentoring at Work: Research, Theory and Practice (Ragins and Kram 2007) and The Blackwell Handbook of Mentoring: A Multiple Perspectives Approach (Allen and Eby 2007)). Although many studies do not specify the exact type of mentoring studied (Allen et al. 2008), we specified, when possible, whether the studies reviewed examined formal or informal mentoring. Articles discussing forms of mentoring other than workplace mentoring (such as student-faculty mentoring) were excluded from the review. We included articles published through 2014. Table 1 shows an overview of key studies included and how these studies relate to the four research areas of this review. We now discuss each of the four areas in detail.

\section{The context of mentoring}

The process of mentoring can take place in several forms, varying from formal developmental interactions such as coaching sessions, to long-term and intense relationships. While current mentoring research is increasingly concerned with developmental networks (e.g. Higgins and Thomas 2001; Van Emmerik 2004), mentoring has traditionally been studied mostly on a dyad level. In these studies, mentoring is seen as a phenomenon that is bounded to one specific relationship: the mentoring dyad.

Studying an isolated mentoring dyad can unveil important dynamics of core concepts such as the impact of diversity, gender, culture and power distance (Ramaswami et al. 2014). For ecological validity, however, the study of mentoring needs embedded- ness in larger social contexts (Chandler et al. 2011). Isolating the two members of a mentoring relationship entails three important limitations. First, such focus overlooks possible influences of other people on the protégé's development. For most people, it would be rare to find someone who can meet all their developmental needs. Early studies already showed that individuals look for support alongside their primary mentor-protégé relationship. Kram and Isabella (1985) showed that various types of colleagues provide developmental support. Their biographical interview study of significant peer relationships identifies the information peer (sharing information with the protégé), the collegial peer (providing career strategizing, job-related feedback and friendship) and the special peer (providing confirmation, emotional support, personal feedback and friendship). Based on the answers to two open-ended questions in a larger survey, Allen and Finkelstein (2003) found that family members, supervisors, colleagues, subordinates and friends provide developmental support comparable to that of mentors. However, for a long time, mentoring studies ignored the influence of others on the protégé's career development.

Second, the interplay between other work relationships and the mentoring relationship is generally overlooked (cf. Kram and Ragins 2007). Mentors and protégés are influenced not only by other mentors and protégés, but also by other work and non-work relationships. Interactions with these individuals may affect the interactions and mentoring processes between mentor and protégé. For example, when a mentor has positive relationships with co-workers, the protégé may perceive his or her own relationships with these co-workers as more favorable than when the mentor has negative relationships with them.

Third, we have little insight into the interplay between mentoring relationships and their organizational context. Studies examining the influence of the organizational context focus on the effects of organizational mentoring programs (Chandler et al. 2011), rather than on how organizational features (e.g. structures, processes, culture) influence the ways in which individuals are engaged in informal mentoring relationships. We have very little insight into how mentoring relationships, in turn, influence their organizational context.

\section{Developmental network research}

Acknowledging that isolating one mentor and one protégé holds important limitations, Higgins and 
Kram (2001) applied a social network perspective to mentoring and reconceptualized mentoring into a multiple-relationships phenomenon. Their developmental network perspective addresses the question of how being engaged in multiple, simultaneous developmental relationships affects one's career development. Developmental networks consist of developers from various social spheres, who can provide varying amounts and types of career and/or psychosocial support (Dobrow et al. 2011). Developmental networks may include mentors, but most likely also consist of other developers, who provide less prominent career and/or psychosocial support. Most developmental network studies explore how structural characteristics of developmental networks (e.g. tie strength, diversity, size) contribute to one's development, or how protégé characteristics influence the shape of one's developmental network (e.g. Cotton et al. 2011; Cummings and Higgins 2006).

Several studies showed that the size of a developmental network may contribute to protégés' career outcomes. The size of one's advice network is positively related to career success (Van Emmerik 2004), the number of developers and the amount of support are positively related to work satisfaction (Higgins 2000), and the number of developmental relationships predicts rank achieved among American academics (Kirchmeyer 2005). The amount of support provided by a constellation of developers may also have positive effects on protégés' outcomes. A longitudinal study by Higgins et al. (2010) showed that the amount of psychosocial support positively relates to protégés' optimism (e.g. flexibility and adaptability in stressful situations), and that increasing the amount of career and psychosocial support results in more optimism later in their career. Other research shows that network diversity (i.e. number of social spheres from which developers come) influences career benefits for protégés (Higgins 2001). The diversity of instrumental relationships contributes to the number of job offers during job searches, and diverse psychosocial relationships foster protégés' confidence in overcoming career obstacles.

The developmental network approach clearly shifts the focus of mentoring research towards the question of how being engaged in multiple, simultaneous relationships influences one's career development. Still other contextual questions in mentoring literature remain unaddressed. First, current research into developmental networks is typically aimed at picturing the network as a whole, rather than picturing the individual dyads that make up this network. As a result, the interplay between several developmental relationships is hardly captured in current developmental network studies. In this way, there is limited insight into how different developmental relationships influence one another. Second, we could extend our understanding of how one's participation in several simultaneous developmental relationships influences behaviors, communications and support functions in these relationships. Both protégé and mentor engage in multiple (non-)work relationships, but we lack insight into spillover effects between those relationships. Third, because of the focus on the network rather than on its distinct dyads, the behaviors and support functions in these various specific developmental relationships - next to the mentoring dyad - are still underexplored. Last, few studies have explored the interplay between organizational context and mentoring. Insights into the mutual influence of organizational characteristics and mentoring processes are scarce.

\section{Future directions: seeing mentoring in its broader context}

The interplay between developmental relationships. Current mentoring research hardly investigates the interplay between several developmental relationships in a network. The developmental network approach is useful in addressing the question of how various developmental relationships influence career progression, but no research has yet explored the way in which developmental relationships influence each other. Kram and Ragins (2007) address this possibility in their conceptualization of relational caches, which they define as 'a transportable sets of relational skills and competencies' (p. 671). They argue that competencies derived from one relationship may affect the processes and outcomes of other relationships. Related fields also show how experiences in one relationship can influence the course of another relationship. For example, in the trust literature (Burt and Knez 1996; Ferrin et al. 2006), there is an increasing understanding of how trust between two members of a relationship is influenced by relationships with third parties. In developmental network research, it would also be valuable to study the effects of third parties on the attitudes and behaviors of protégés and mentors. For example, when a mentor has more than one protégé, how does the diffusion of the mentor's attention affect protégés' evaluations (Bozeman and Feeney 2008)? As Hall and Chandler (2007) state, it is likely that an individual's current work life is composed of several mini learning cycles and, therefore, 
individuals act like newcomers several times during their careers. Following this idea of career paths, it might be the case that an individual is protégé in one mentoring relationship, but mentor in another, simultaneous relationship. Future research using sociometric surveys could examine how attitudes and behaviors in one relationship are influenced by other relationships, and explore the mediating factors that affect these processes.

Multiplexity in developmental networks. Previous studies on developmental relationships generally suppose that both members of the relationship have only one role in their relationship (Dobrow et al. 2011). With few exceptions (e.g. Cotton et al. 2011), developmental network research has not examined the possibility of simultaneously fulfilling different roles in one relationship. These different roles are called 'multiplexity', which is 'the overlap of roles, exchanges, or affiliations in a social relationship' (Verbrugge 1979, p. 1286).

Cotton et al. (2011) focused on the multiplexity of support functions provided by developers. They found that some developers demonstrate multiplexity by providing multiple career subfunctions or multiple psychosocial subfunctions in one relationship. Further, protégés described hybrid multiplexity relationships in which one single developer provides both career and psychosocial support. To extend this research line, it would be helpful to examine the effects of other multiplexity forms. Nowadays, work and non-work are seen as connected and having important mutual influence, making the occurrence of spillover effects between those domains likely. A protégé's colleague (work developer) can also be his or her friend (nonwork developer). To date, no studies have examined the consequences of multiplexity between work and non-work roles in a developmental network context. It would be useful to explore how simultaneous roles may, for example, influence the multiplexity of communication topics, or the range of support functions provided in a developmental relationship.

The content of dyads in developmental networks. Next, developmental network research has given scant attention to network content (Cotton et al. 2011). We have insufficient insight into how the support functions, phases and behaviors of protégés and developers are similar or different for various developmental relationships. Ragins and Cotton (1999) have already shown that formal mentoring relationships may differ from informal mentorships in terms of the amount of support that protégés receive. Recent evidence suggests that Kram's (1985) original mentoring functions to 'other' developmental relationships may be less generalizable than previously thought (Cotton et al. 2011; Murphy and Kram 2010). These studies add several subfunctions to Kram's (1985) classic set. Cotton et al. (2011) qualitatively examined support functions provided to Major League Baseball players and added subfunctions such as 'freedom and opportunity for skill development' and 'inspiration and motivation.' Murphy and Kram (2010) examined how work and non-work developers contribute to one's career success and added 'encouragement and emotional support' and 'work-life interface failure' as functions. These studies show the importance of a careful exploration of support functions. It seems reasonable as well that particular characteristics of the dyad in terms of gender and race influence the content of the relational interactions (Durbin and Tomlinson 2014). Future studies should extend this research by qualitatively exploring how functions, behaviors and relationship phases differ for various types of developmental relationships (varying in, for example, relationship strength and frequency of contact).

The interplay with the organizational context. Although the relationship between individual characteristics and mentoring has been studied widely, the relationship between organizational characteristics and mentoring has not. We propose a mutuality perspective to examine the interplay between mentoring relationships and their broader organizational context. First, scholars may examine how the organizational context influences mentoring relationships. Chandler et al. (2011) distinguish several levels of analysis. One of these levels is the organizational microsystem, in which researchers focus on how the organizational context shapes mentoring processes. So far, only a few empirical investigations have focused on this level, testing, for example, the influence of an organization's culture and beliefs, hierarchy and reward systems on mentoring (e.g. Ghosh 2014; Hu et al. 2014; Rohatinsky 2014). Future studies could examine how variations in gender at organizational levels influence mentoring processes: Do protégés in a context of corporate masculinity report needs and support functions other than those of protégés in feminine contexts (McKeen and Bujaki 2007)? Scholars may also examine how the position of mentor and protégé in an organization's structure affects their attitudes towards mentoring and mentoring behaviors: How do mentoring relationships in self-managing teams, for 
example, differ from those in organizations with clear senior-junior relationships?

Second, no study has yet examined how developmental relationships, in turn, influence their organizational context. We have very little insight into the ways in which mentors and protégés show their mentorship to other organizational members: Do they express their bond in public, and through which actions and rituals? There are only a few studies on how mentoring is sensed by colleagues in work contexts and how their reactions influence both members. As Scandura (1997) explained, issues of fairness and justice may be important to examine in any mentoring context, since non-protégés may experience negative favoritism. Future research could closely examine the relationship between mentoring and procedural, distributive and interpersonal justice among protégés and non-protégés.

\section{Temporal influences on mentoring}

A complete theory includes the specific context in which a phenomenon occurs, as well as the temporal factors that affect the theorized phenomenon under study (e.g. George and Jones 2000; Whetten 1989). Applying a cross-sectional design (Allen et al. 2008), many mentoring studies isolate single mentoring moments and leave out such temporal factors. This hinders our understanding of mentoring in three ways.

First, there is insufficient understanding of how mentoring relationships evolve over time. Kram (1983) identified four stages of mentoring based on open-ended interviews with 15 young managers and their informal mentors, which was largely supported in a quantitative study by Chao (1997). In the first phase (initiation), the mentor offers the protégé mainly career support. In the second phase (cultivation), the range of career and psychosocial support offered by the mentor increases rapidly to a maximum, although this finding was not supported by Chao (1997). The third phase (separation) is characterized by a decline in career and psychosocial support provided by the mentor, caused by the career development of one or both individuals. Finally, interactions between mentor and protégé evolve in a new form, in which the mentor provides occasional support or the relationship ends (redefinition). There are other models with three (Missirian 1982) and six stages (Phillips 1977). In a comparative study, Pollock (1995) tested hypotheses for these three models. Missirian's (1982) three-stage model was supported, there was some support for Kram's (1983) model, and little support for Phillips' (1977) six-stage model. In all, few studies describe stages of mentoring relationships, and their findings are not fully consistent. Furthermore, it is uncertain whether these models are still valid in modern work contexts. ICT has affected the course of mentoring relationships and the support functions provided in the various stages. It is nowadays possible to have contact with a possible mentor even before a first face-to-face meeting. The initiation phase of mentoring relationships may start in virtual ways. The redefinition phase could differ from the previous models, as virtual communication allows people to interact with each other even when they are physically separated. Further research should also examine how career mobility has affected the depth and quality of mentoring relationships and, accordingly, the support functions provided in the different phases.

Second, we have an incomplete understanding of how long-term interpersonal processes between mentors and protégés evolve. Most studies conceptualize how individual characteristics such as gender (Young et al. 2006), race or personality (Hu et al. 2008) influence formal and informal mentoring. Still, we have only limited insight into how typical relational factors (such as trust, disclosure, interdependence or relationship commitment) unfold in mentoring relationships. How do members' perceptions of these processes influence the course of mentoring relationships?

Last, influences of a mentoring history on current mentoring relationships have hardly been investigated. Ragins and Scandura (1999) drew attention to spillover effects in consecutive informal mentorships when explaining individuals' willingness to mentor. They concluded that individuals with experience both as mentor and as protégé expected greater benefits and fewer costs of being a mentor than individuals with experience only as a mentor. A mentor's positive experience as protégé predicts expected outcomes when becoming a mentor. Such important findings hint at the significance of previous mentoring experience, but to date no study has unpacked how these previous experiences influence mentoring relationship dynamics.

\section{Developmental changes over time}

Recently, more studies have applied a longitudinal approach to mentoring (Allen et al. 2008). Most of these examine whether mentoring leads to long-term outcomes such as organizational commitment (Donaldson et al. 2000; Payne and Huffman 2005), career 
success (Blickle et al. 2009) or organizational knowledge sharing (Bryant 2005). Some studies also examine how individual characteristics relate to receiving mentoring (Blickle et al. 2010; Singh et al. 2009) or one's willingness to mentor in the future (Wang et al. 2009).

While insights into how one's professional development changes over time are important, they ignore how mentoring relationships and the interpersonal processes in mentoring relationships change over time. For example, Dobrow and Higgins (2005) showed that developmental network density relates negatively to professional identity clarity, but this type of study typically sidesteps how identity clarity is accomplished in mentoring relationships. Bouquillon et al. (2005) found no significant differences across the various mentoring stages for protégés' trust and identification in their study on both formal and informal mentoring. They did not examine the process of how trust is built (i.e. which actions are perceived as signs of trust, and how this influences members' behaviors). It would be useful to understand how such interpersonal processes unfold and vary over time, and how this influences members' attitudes, behaviors and outcomes. There are some studies that show temporal aspects of stage models, such as Mezias and Scandura (2005), who illustrate different mentoring roles relevant for expats over time. For strategic implications, such as designing formal mentoring programs, however, more research is needed on the unfolding of mentoring relationships.

\section{Future directions: a life cycle approach of mentoring relationships}

Influence of specific events on the course of mentorships. We propose two research lines to capture the life cycle of mentoring relationships, including both macro and micro changes. First, we need to zoom out on mentoring relationships to map macro changes. This will provide a balanced view of how mentoring relationships change over time. It would be fruitful to identify how specific events in mentoring interactions relate to positive or negative change. We propose two research approaches. Turning point analysis investigates the changing nature of relationships by examining events that contribute to specific changes. Turning points are events that create positive or negative changes in a relationship, and are associated with relational satisfaction, commitment and metacommunication (Baxter and Bullis 1986). Examining turning points may lead to a better un- derstanding of which events relate to change in mentoring relationships. An appropriate method here is the Retrospective Interview Technique. Participants are asked to identify turning points in their mentoring relationship, which are graphically plotted on a time line. They also report on dependent variables such as their commitment level or relationship satisfaction on those specific points in time, so the researcher can analyze how particular turning points change interpersonal processes such as trust, commitment and closeness.

The Critical Incident Technique (CIT) is an open method that focuses on positive and negative incidents, which allow participants to mention any event that comes to mind. Originally, the CIT was developed as a technique for observing human behavior and deciding on the competence needs of professionals (Flanagan 1954). Participants are asked to recall and describe experiences in detail about which they have outright positive or negative feelings. Participants are asked to describe what exactly happened, who were involved, and what the effect of the specific incident was on, for example, relationship satisfaction, commitment or relationship quality. Specific incidents, both positive and negative, give insight into the content of mentor-protégé relationships and into the way mentoring relationships evolve.

Second, we need to zoom in on specific stages of the mentoring relationship. For example, we have limited insight into the endings of mentoring relationships. Previous studies showed that there are physical and psychological (e.g. jealousy, outgrew) reasons to terminate a mentoring relationship (e.g. Ragins and Scandura 1997). However, we lack insight into specific incidents causing a mentoring relationship to end, and behaviors for ending mentorships. It is also unclear why some social interactions at work will lead to mentoring relationships, while others will not. Once a mentoring relationship results from these social interactions, it keeps changing. When members violate norms, both mentor and protégé will reestablish a new form of mentoring relationship. However, we know little about such relational dynamics and how these influence the evolution of mentoring relationships.

Mentoring schema theory. Mentoring schema theory (Ragins and Verbos 2007) could be helpful in exploring the influence of members' personal history. Based on relational schemas (Baldwin 1992; Planalp 1985, 1987), researchers could examine how mentoring schemas influence members' behaviors in their 
contact with partners (Chandler et al. 2011). Mentoring schemas are 'cognitive maps derived from past experiences and relationships that guide mentors' and protégés' perceptions, expectations, and behaviors in mentoring relationships' (Ragins and Verbos 2007, p. 101). These schemas include mental representations about general roles of mentors and protégés (i.e. 'mentors are experts') as well as specific mental representations reflecting mentor and protégé roles in their specific relationship (i.e. 'my mentor takes the lead during conversations'). It would be interesting to study how these cognitive maps relate to the evaluation of the behaviors of both partners. For example, how are the actions of mentors in a current mentorship affected by their own experiences as protégés? Perspective-taking could play a role here. Perspective-taking needs a process in which meaning analysis takes place: 'an implicit or explicit shift in the manner in which a situation is experienced' (Arriaga and Rusbult 1998, p. 929). Previous studies on perspective-taking (e.g. Batson et al. 1997) showed that imagining how you would feel in a situation creates empathy, but also personal distress, which evokes egoistic motivation. However, imagining how the other feels produces empathy, which evokes altruistic motivation. It could be that mentors with experience as both mentor and protégé will be better able to imagine how the other feels, evoking altruistic motivation. Future research may examine how both perspectives lead to different motivations and behaviors of both members, and how these influence members' satisfaction.

\section{Underlying developmental mechanisms of mentoring}

One of the most studied topics in mentoring literature is the outcomes of mentoring (Allen et al. 2008). Both formal and informal mentoring are associated with several behavioral, attitudinal and career benefits for protégés and mentors (Allen et al. 2004; Eby et al. 2008a; Ghosh and Reio 2013). However, there is criticism of studies investigating beneficial outcomes of mentoring. First, most studies use cross-sectional designs. Although these studies give insight into which key variables are related to one another, they are not suitable to prove cause-and-effect relationships. It is unclear whether positive outcomes related to mentoring are indeed a result of mentoring activities. Another explanation would be that protégés already hold such positive characteristics and work attitudes, which may be why they are selected by informal mentors in the first place (Allen et al. 2008; Ragins and Cotton 1993).

Moreover, mentoring research has been criticized for consisting of one-shot empirical data, rather than theory-based studies. Mentoring literature lacks 'an integrated research model or framework' (Burke and McKeen 1997, p. 44), resulting in empirical listings showing that mentoring could be useful, without providing theoretical explanations for these results: 'findings are abundant but explanations are not' (Bozeman and Feeney 2007, p. 720). There is still a black box of mentoring processes and interactions. Only with a clear understanding of underlying mechanisms can we address the question of why mentoring processes are effective. Without such models, this question is still one of the most pressing agenda items in mentoring research (Bearman et al. 2007). Mentoring research would benefit from studies that contribute to understanding of the exact relationship between mentoring and positive outcomes.

\section{Mediating factors as explanation for developmental change}

In recent years, some attempts have been made to come up with explanations for the working of mentoring. These studies include mediating factors that could explain the underlying mechanism of mentoring and positive outcomes. Baranik et al. (2010) drew on social exchange theory and showed that perceived organizational support partly explains the relationship between supervisory mentoring and protégés' work attitudes. Perceived organizational support is a social exchange relationship between employees and their organization, and refers to employees' perceptions about the degree to which the organization cares about their well-being and values their contribution. Baranik et al. (2010) argue that mentors serve as agents of the organization, who, by providing support functions, influence protégés' perceived organizational support, which in turn predicts work attitudes such as job satisfaction and commitment. Perceived organizational support thus serves as an explanatory mechanism for understanding why certain mentoring functions predict protégé job satisfaction and commitment.

Pan et al. (2011) drew on personal learning perspective to explain why supervisory mentoring influences protégés' job performance and career satisfaction. They proposed that both personal learning and self-efficacy are important concepts for mentoring. 
They showed that supervisory mentoring leads to personal learning, which in turn predicts job performance and career satisfaction. Employees' self-efficacy has a dual moderating effect on the impact of mentoring on protégés' career outcomes.

Both studies extend understanding of underlying mechanisms. Still, there is much work to do in uncovering such mechanisms. Next to social exchange theory and a personal learning perspective, insights from related fields could be useful in examining mentoring processes and mechanisms. We discuss two possible approaches to examine (1) how need-fulfilment processes in mentoring relationships are related to mentoring effectiveness, and (2) how relational dynamics in mentoring interactions constitute mentoring relationships.

\section{Future directions: uncovering developmental mechanisms}

Self-determination theory. Self-determination theory (SDT) is a theory of human motivation (Deci and Ryan 1985, 2012). It considers people as actively engaged, growth-oriented organisms who interact with their environment and strive towards intra- and interpersonal growth. Self-determination theory has been applied in various research contexts, such as education (Vansteenkiste et al. 2004), health care (Ryan et al. 2008) and organizations and work (Deci et al. 1989). The key idea of SDT is that humans have three basic needs: autonomy, competence and relatedness. Autonomy refers to having the experience of acting with a sense of self-choice and self-determination. Note that autonomy in SDT has a meaning different from that in traditional mentoring literature. Acting autonomously does not mean acting independently, but it means a sense of self-directedness in one's actions (Stone et al. 2009). Competence means feeling capable, and acting with a sense of confidence and effectiveness. Relatedness refers to being engaged in satisfying, encouraging relationships. According to SDT, the fulfilment of these three needs together promotes people's self-motivation, effective functioning and relationship satisfaction. Similar to what SDT calls innate growth tendencies of people (Deci and Ryan 2000), processes of development and growth are central in mentoring relationships. Accordingly, we argue that the fulfilment of autonomy, competence and relatedness plays a crucial role in mentoring relationships, even more than it does in other work relationships (e.g. leader-member exchange).
Self-determination theory can be applied in several ways. For example, researchers could examine under what circumstances employees are motivated to perform mentoring behaviors. Second, SDT examines how the fulfilment of autonomy, competence and relatedness relates to psychological health and well-being. In line with relational mentoring (Ragins 2012), scholars could adopt a need-based approach in their studies and examine how the fulfilment of both mentors' and protégés' needs is related to relationship functioning. In a first examination of needs fulfilment in mentoring, Janssen et al. (2013) examined qualitatively how protégés' needs for autonomy, competence and relatedness are fulfilled by their developers. This study showed the importance of need-supportive developmental functions, including encouraging self-initiation (autonomy), confirming and praising competent behaviors (competence), and intimacy and self-disclosure (relatedness). Although we assume that mentoring relationships may be especially important in meeting the need for competence, SDT research shows that the presence of support for all three needs is important. Future studies could examine further how need fulfilment processes are related to relationship functioning. Informal mentoring relationships are most likely need-driven (Ragins and Cotton 1999) more than other (formal) work relationships; it is therefore crucial to gain insight into the fulfilment of basic needs and the alignment between mentors and protégés in their expectations regarding needs fulfilment. Future studies may also examine how mentors' basic needs are fulfilled by their mentoring relationships. Deci et al. (2006) showed that both receiving and giving autonomy support relate to need satisfaction. Mentors who give autonomy support to their protégés may thus also experience need satisfaction. The application of SDT in mentoring research is still in its infancy (e.g. Janssen et al. 2014; Sun et al. 2014), but offers promising directions for research on mentoring mechanisms.

Relational leadership theory. A second potentially relevant research approach involves the study of mentoring microprocesses. Insights from relational leadership theory (Uhl-Bien 2006) could be helpful. Relational leadership 'does not focus on identifying attributes of individuals involved in leadership behaviors or exchanges, but rather on the social construction processes by which certain understandings of leadership come about and are given privileged ontology' (Uhl-Bien 2006, p. 655). While current mentoring research is most concerned with 
individual characteristics, cognitions and behaviors, future research could benefit from a focus on the relational dynamics that talk mentoring relationships into being (Weick et al. 2005). This enables the investigation of how relationships emerge in communication, rather than taking communication as the vehicle to express pre-existing realities (Brummans et al. 2014; Christensen and Cornelissen 2011). Portraying relationships as ongoing and precarious accomplishments that are realized, experienced and identified mainly - if not only - in communication processes (Cooren et al. 2011) could unveil their underlying dynamics. From this perspective, mentoring is not just the result of a combination of members' individual properties, but a self-organizing process of interactions. The positions of both mentor and protégé are constructed and sustained in interaction (cf. DeRue and Ashford 2010). These interactions continuously define and redefine mentoring. This approach allows us to study the complex dynamics of interactions between mentor and protégé. For example, researchers could use conversation analysis to explore how agreements between mentors and protégés get negotiated, how protégés' developmental needs are diagnosed, and how developmental strategies are enacted. This way, we may get a grip on how such microprocesses contribute to developmental growth.

\section{Relational motivations of both mentors and protégés}

Social exchange theory (Blau 1964; Emerson 1976) is one of the most influential paradigms in organizational behavior literature, and also strongly influenced mentoring research. A basic assumption of this paradigm is that individuals form social relationships because they expect them to be rewarding. As such, it imposes a transactional view on relationships: there has to be a balance between the exchanged (expected) costs and benefits. Mentoring relationships are then about exchanges of support behaviors throughout the relationship (Young and Perrewé 2000).

Social exchange theory leads to a cognitive and instrumental view on mentoring. As Ragins and Verbos (2007) critiqued, scholars often see mentoring relationships as one-sided relationships leading to instrumental outcomes for the protégé. The influence of this view is highly visible in current mentoring literature. First, when studying how and why people engage in mentoring relationships, scholars often focus on members' attractive characteristics (Olian et al. 1988, 1993). The willingness to mentor is proposed to be based on a weighing of costs and benefits, a rational calculation (Ragins and Scandura 1999). Developmental network research also adopted this instrumental view on relationships. Drawing on a social exchange model, researchers form ideas of developmental networks as instrumental means for career mobility, and typically focus on the use of networks to benefit protégés' careers. As a result, relational motivations to engage in mentoring relationships, such as the need for connectedness and belonging, are neglected.

Career development is traditionally seen as an individual process, aimed at individual mastery, differentiation from others and vertical progression. Protégés' development is optimal when the protégé is a competent and independent professional. This 'show me the money approach' (Ragins and Verbos 2007, p. 95) leaves little space for relational outcomes such as mutual growth and one's ability to function in a context of interdependence and connection (Fletcher 1996).

Mentors' needs and benefits are usually neglected in this approach. In their meta-analysis, Allen et al. (2008) showed that mentoring research is overshadowed by single-source data, with a strong focus on protégés. As a reaction to this imbalance, some scholars recently shifted towards the mentor as a research object. For example, mentors' positive outcomes (Allen et al. 2006b, Bozionelos 2004), negative experiences (Eby et al. 2008b) and willingness to mentor (Allen 2003; Hartmann et al. 2014; Van Emmerik et al. 2005) were studied. However, the protégé is still the primary member to include in studies, also in developmental network research (Dobrow et al. 2011). Researchers have not yet studied developers' perspectives, experiences and expectations.

\section{Relational mentoring theory}

Current discourse about vocational behavior involves the importance of relationships in organizational life and increasingly focuses on relational skills and competencies, aimed at interdependence and connection with others (Blustein 2011; Blustein et al. 2004; Flum 2001; Hall 1996). In the upcoming stream of positive organizational scholarship (POS) (Cameron and Spreitzer 2011; Cameron et al. 2003) and inspired by Stone Center relational cultural theory (Jordan et al. 1991; Miller 1976), relational mentoring theory questions instrumental approaches towards mentoring held by traditional mentoring literature, and 
provides an alternative lens for looking at mentoring (Ragins and Verbos 2007). The theorizing of relational mentoring underlines the positive, mutual developmental experience of being in a connection, rather than exchanges of resources based on expected benefits. Relational mentoring shows that current studies ignore a large array of phenomena associated with mentoring. For example, traditional mentoring research tends to ignore relational skills such as empathy, authenticity and vulnerability, while these are special research areas in relational mentoring (Fletcher and Ragins 2007).

In line with the 'positive deviance' of POS, relational mentoring focuses on so-called 'high-quality mentoring relationships'. However, concepts of relational mentoring should not necessarily be limited to the study of high-quality mentoring relationships. Ideas coming from relational mentoring could inspire scholars to broaden their view when studying traditional mentoring relationships. We agree with Allen and Eby (2007) that the need to belong could be a basic motivational factor to engage in mentoring relationships. Relatedness is then seen as a key need for both mentors and protégés.

Integrating a relational perspective on mentoring would lead to a balanced view on mentoring. First, insights from relational mentoring theory could broaden our scope when examining motives of members to engage in mentoring relationships and mentoring outcomes. Until now, most researchers have used social exchange theory to explain why mentors and protégés engage in mentoring relationships. However, this leaves little space for motives such as human strivings for connection and the need to belong. Second, relational mentoring stresses the importance of seeing mentoring as a mutual relationship. Incorporating a relational approach would shed light on the interplay between mentors and protégés. In the following sections, we show how these ideas from relational mentoring theory can help us to create a balanced view on mentoring, with room for relational processes and motivations, for mentors' perspectives and for dyadic processes.

\section{Future directions: towards a balanced view on mentoring}

The need to belong as motivational factor. In their theoretical contribution, Allen and Eby (2007) showed that their idea of how the need to belong serves as a driving mechanism for the engagement in mentoring relationships. A felt sense of belonging makes being connected in a mentoring relationship effective in that mentoring processes create positive affective, cognitive and behavioral outcomes. This fulfilment of the need to belong is comparable to what SDT calls relatedness. According to SDT, this need to feel connected to others is one of people's basic needs. In particular, for protégés who are newcomers in their organizations, it may be important to feel a sense of connectedness with others (e.g. with their mentors). Self-determination theory could inspire scholars to focus on relatedness as a central aspect in mentoring relationships. For example, Janssen et al. (2013) highlighted the importance of including support functions aimed at relatedness in their study about developmental relationships by adopting a SDT perspective. Their SDT framework complements Kram's (1985) classic set of career and psychosocial support functions. The SDT categories of competence and autonomy have been included in previous mentoring studies, but relatedness has mostly been overlooked. Although relatedness functions can be tracked in Kram's (1985) support functions (e.g. friendship and protection), Janssen et al. (2013) showed a broader picture of belonging and interpersonal sensitivity, with functions such as intimacy, self-disclosure and caring. These outcomes underline the importance of the need for relatedness in mentoring relationships. Future research could more closely examine how mentors' needs for relatedness are fulfilled in their mentoring relationships. For example, Janssen et al. (2014) show how relational motivations (e.g. the need to form and maintain close relationships with others) play a role in mentors' motives to mentor.

In addition, future studies could deepen our understanding of relational functions and processes of mentoring, for example by focusing on processes such as personal learning, mutual respect and identity formation (Ragins 2012). In particular, when including developers from various social spheres, the diversity of support functions provided could be large. Future studies could explore whether non-work developers, for example, provide support functions aimed mainly at relatedness, while work developers focus mainly on competence.

The mentor's needs. Although progress is made in getting insight into mentors' perspectives, this line of research could be further extended. For example, scholars could examine developers' needs and motives for engaging in a developmental relationship. Again, SDT could be helpful for studying both members' motives to engage in mentoring 
relationships (Haggard et al. 2011; Janssen et al. 2014). Self-determination theory sees motivation as a continuum from non-internalized (controlled) to internalized (autonomous) reasons. According to SDT, both contextual and interpersonal factors can promote the internalization of external requirements into autonomous motivations. The more internalized an extrinsic motivation, the more autonomous the person will be when performing the behaviors (Deci and Ryan 1985). As shown by Janssen et al. (2014), this means that some informal mentors have mainly extrinsic motivations to help the protégé (e.g. 'I do this because it is part of my job'), while others have mainly intrinsic motivations (e.g. 'I enjoy doing this'). Researchers may extend this line of research by examining motives of, for example, formal mentors. These mentors are likely to describe different extrinsic motivations, as previous studies using SDT show that more controlling social contexts (e.g. formal mentoring programs with prescribed formats) may inhibit the internalization process (Deci and Ryan 2000). Selfdetermination theory could also be helpful when examining mentors' needs. In their study, Janssen et al. (2013) showed how being engaged in developmental relationships helps protégés to fulfil their needs for autonomy, competence and relatedness. However, it is likely that mentors' basic needs are also fulfilled by their interactions with protégés. Future research could examine how mentors' need fulfilments are similar to or different from those of protégés.

Mutuality in mentoring relationships. Although scholars increasingly include the mentor as a research object, developmental relationships are mostly still conceptualized and measured as if there are two detached actors, instead of focusing on the interaction between those two actors (Dobrow et al. 2011). Most mentoring studies focus on members' individual behaviors, attitudes or characteristics, instead of their interactions. Concepts of relational mentoring could inspire researchers to focus on both members. This theory sees mutuality as central in mentoring processes, and therefore understanding the concept of mentoring needs a direct focus on the interaction between both members. One way of carrying out this relational focus in studies is by sampling both members. In their review, Wanberg et al. (2003) encourage scholars to adopt a dyadic approach to data collection and analysis. However, only a few mentoring researchers actually included such a dyadic approach (Allen et al. 2008). We discuss some examples to give an outline of this emerging research line. Although studies in which one member of the dyad provides information about both members could also be seen as dyadic studies (e.g. Kao et al. 2014), we discuss only studies in which the sampling procedure of the study involves both members of the relationship.

Researchers have conducted dyadic studies in which predominantly both protégés and mentors report on their own and partner's individual characteristics. In this way, similarity and differences between those characteristics can be calculated. For example, Allen et al. (2006a) examined design features of formal mentoring programs and perceived program effectiveness from both mentor and protégé perspectives. Specifically, they examined how program experiences of the protégé (e.g. input into the mentoring process, program understanding and perceived mentor commitment) relate to mentor perceptions of program effectiveness. They found that protégés' reports of mentor commitment and program understanding related to perceived program effectiveness. Godshalk and Sosik (2000) examined whether the degree of similarity between mentor and protégé about mentor transformational leadership behavior would influence the perceived quality of mentoring relationships. Based on difference scores between protégés and mentors, they classified mentors as (1) underestimators of their transformational leadership behavior, (2) being in agreement with their protégé or (3) overestimators of their transformational leadership behavior. They found that mentors who agree with their protégés were indeed associated with higher levels of relationship effectiveness and psychosocial support, compared with mentors who were overestimators. However, contrary to their hypotheses, underestimators were associated with the highest quality of mentoring relationships. In another study, Godshalk and Sosik (2003) examined whether mentor-protégé agreement about learning goal orientation would influence the level of mentoring functions received by the protégé. Results showed that protégés who hold high levels of learning goal orientation similar to those of their mentors were associated with the highest level of psychosocial support.

Although these studies provide insight into how similarity of mentors' and protégés' characteristics influence perceived quality and relationship effectiveness, they have two limitations. First, these studies focused on individual characteristics only, such as behaviors, attitudes and demographics. They do not give insight into how both members agree or differ in relationship properties. Only a handful of studies have included relational characteristics such as 
relationship length (Waters 2004), loyalty (Raabe and Beehr 2003), frequency of meetings (Waters 2004) and contact time with the mentoring partner (Lankau et al. 2005). Second, most often only group differences between mentors and protégés were analyzed. Protégés' responses as a group are compared with mentors' responses as a group. Although this provides insight into how, for example, perceptions of protégés as a group differ from mentors' perceptions, these results do not necessarily mean that these differences occur within any particular mentoring relationship (cf. Maguire 1999).

As we can see, scholars mostly addressed mutuality by including individual characteristics of both members in their studies, rather than studying their relational properties. Although progress is made in this way, many dyadic questions are still left out. A dyadic approach that also addresses relational characteristics would allow for a better understanding of the factors involved in the process of mentoring.

\section{Concluding notes}

The purpose of this paper was to review prior research on informal mentoring at work and to identify research opportunities for future research. Based on two basic premises of interpersonal relationships, we explored research areas that represent fruitful avenues for future research. We discussed how current developments in mentoring literature can cultivate these research areas and thus can contribute to a fuller picture of the concept of mentoring. We showed how insights from adjacent fields can contribute to the advancement of mentoring research. In this final section, the main conclusions from this review are drawn.

First, this review shows that the context of mentoring deserves more research attention. Although developmental network researchers incorporate multiple developmental relationships in their studies, other work relationships and the organizational context are most often left out. Moreover, most developmental network research focuses on the network as a whole, and focuses less on the specific individual dyads within such a network. This review offers various suggestions to extend the developmental network approach. We believe it would be fruitful if mentoring research zoomed in on the specific dyads within networks, to examine carefully (e.g. with in-depth studies) the circumstances of and processes within these various dyads. This would lead to a better understanding of the broader context in which mentoring processes are embedded, and the influence of how a context sets boundaries and provides opportunities for the occurrence of mentoring processes. It would also provide insight into how these mentoring processes influence their context.

Second, this review shows that few mentoring studies incorporate temporal influences in their conceptualization and measurement. As a result, there is limited knowledge of how mentoring processes evolve, how interpersonal processes between mentors and protégés unfold, and how previous mentoring behaviors influence current mentoring behaviors. We discussed various research suggestions to include temporal factors in mentoring studies, in both conceptualizations and measurements. These suggestions will lead to a better understanding of the full life cycle of mentoring relationships and thereby will enable the broader contextualization for studies focusing on one mentoring phase.

Third, mentoring literature has a strong focus on studying outcomes of mentoring. However, it provides little insight into the underlying developmental mechanisms that cause these outcomes. Future research needs to illuminate the processes that form the basis of developmental changes. We suggest that researchers adopt need-perspectives (e.g. SDT) in their conceptualizations of underlying mechanisms, in addition to social exchange paradigms. Although social exchange rules apply to mentors' and protégés' motives to engage in mentoring relationships, other motivations may be important as well.

Fourth and finally, this review shows that more research is needed incorporating both members in conceptualizations, sampling, measurements and analyses. For example, we have shown how insights from relational mentoring theory could be helpful in examining relational motivations of both members. Also, it would be valuable if researchers invested in conducting observational studies, as this would permit scholars to get a view of how both members enact their mentoring relationship.

Apart from the conclusions directly derived from this review, we call for taking alternative ontological assumptions about mentoring into consideration. We chose to review the available literature and make suggestions to move on from there, rather than stressing the relevance of the alternative paradigmatic conceptualization of relationships of process studies. In the concluding section of this paper, we want to come back to this blind spot in the literature and sketch two possible starting points for exploring a more constructionist approach to mentoring studies. First, we 
encourage colleagues in the field of mentoring studies to familiarize themselves with the process approach and the questions it poses. This exploration challenges basic assumptions of a more traditional take on the social sciences from a constructionist view (e.g. Berger and Luckmann 1966; Burrell and Morgan 1979; Langley and Tsoukas 2010; Rescher 1996; Van de Ven and Poole 2005; Weick 1995). A good starting point could be to think through the three questions that Pratt (2012) posed in rethinking the concept of 'identity' as a construction process, but now for (mentoring) relationships. First, can we meaningfully talk about relationships and process (stressing change, flux and becoming rather than cohesive and enduring characteristics)? By answering this question with 'yes', one would learn to "view those things that appear stable and persistent as actually comprised of multitude of activities, expressions and small (or not so small) changes' (Pratt 2012, p. 24). Second, if we can meaningfully talk about (mentoring) relationships and process, how should we talk about them? This would draw attention to new vocabulary to describe how people engage in relationships, such as 'doing relationships', 'relationship construction' and 'relationship work' (cf. Pratt 2012, pp. 28-30). By taking this perspective - largely overlooked in mentoring research - studies would stress how individuals participate actively in practicing relationships rather than conforming to relationship information given by others. Third, if we know how to talk about (mentoring) relationship processes, what is missing from current conversations? The underexamined processes that Pratt (2012) identified (i.e. intertwining dynamics of expecting, accepting, expressing and reflecting) could be very informative for mentoring studies as well. By exploring such questions, scholars could evaluate their position within this discussion.

Second, next to conceptual explorations of a process philosophy, a more practical starting point would be considering constructionist research designs for studying mentoring. Several authors (e.g. Hernes and Weik 2007; Van de Ven and Poole 2005) propose taxonomies of approaches in which entity and process are two ends of a continuum. As this review has shown, the entity approaches are well established. We invite scholars to pose research questions about mentoring relationships within the more processual quadrants, which opens up new avenues for research. For example, studies on relationships as process (approach III, in Van de Ven and Poole 2005) enables a sensemaking perspective of the ways in which people enact scripts that inform their expectations and hopes for the men- toring relationship. Through these scripts about what it means to be a mentor or a protégé, meaningful interactions emerge. Alternatively, stressing 'process as connectivity' (Endegenous view 1, in Hernes and Weik 2007) takes the mentoring relationship as a process of connecting that evolves and stabilizes. This stresses the co-construction of relationships, avoiding the trap of (in Alfred Whitehead's terms) the fallacy of misplaced concreteness and thereby make the relationship (in Bruno Latour's terms) the explanandum (what has to be explained) rather than the explanans (what explains). Exploration of transformation processes of informal contacts into mentoring relationships may explain how a historically filled label influences their interactions. In all, this sketchy overview of available process approaches points in new directions for mentoring studies that could fundamentally redefine the underlying assumptions of what it is to engage in the type of relationships people happen to call developmental relationships.

\section{References}

Allen, T.D. (2003). Mentoring others: a dispositional and motivational approach. Journal of Vocational Behavior, 62, pp. 134-154.

Allen, T.D. and Eby, L.T. (2004). Factors related to mentor reports of mentoring functions provided: gender and relational characteristics. Sex Roles, 50, pp. 129-139.

Allen, T.D. and Eby, L.T. (2007). Common bonds: an integrative view of mentoring relationships. In Allen, T.D. and Eby, L.T. (eds), The Blackwell Handbook of Mentoring: A Multiple Perspectives Approach. Oxford: Blackwell, pp. 398-419.

Allen, T.D. and Finkelstein, L.M. (2003). Beyond mentoring: alternative sources and functions of developmental support. Career Development Quarterly, 51, pp. 346-355.

Allen, T.D., Eby, L.T. and Lentz, E. (2006a). The relationship between formal mentoring program characteristics and perceived program effectiveness. Personnel Psychology, 59, pp. 125-153.

Allen, T.D., Lentz, E. and Day, R. (2006b). Career success outcomes associated with mentoring others: a comparison of mentors and nonmentors. Journal of Career Development, 32, pp. 272-285.

Allen, T.D., Eby, L.T., Poteet, M.L., Lentz, E. and Lima, L. (2004). Career benefits associated with mentoring for protégés: a meta-analysis. Journal of Applied Psychology, 89, pp. 127-136.

Allen, T.D., Eby, L.T., O’Brien, K.E. and Lentz, E. (2008). The state of mentoring research: a qualitative review of current research methods and future research implications. Journal of Vocational Behavior, 73, pp. 343-357. 
Arriaga, X.B. and Rusbult, C.E. (1998). Standing in my partner's shoes: partner perspective taking and reactions to accommodative dilemmas. Personality and Social Psychology Bulletin, 24, pp. 927-948.

Baldwin, M.W. (1992). Relational schemas and the processing of social information. Psychological Bulletin, 112, pp. 461-484.

Baranik, L.E., Roling, E.A. and Eby, L.T. (2010). Why does mentoring work? The role of perceived organizational support. Journal of Vocational Behavior, 76, pp. 366373.

Batson, C.D., Early, S. and Salvarani, G. (1997). Perspective taking: Imagining how another feels versus imagining how you would feel. Personality and Social Psychology Bulletin, 23, pp. 751-758.

Baugh, S.G. and Fagenson-Eland, E.A. (2007). Formal Mentoring Programs: A 'Poor Cousin' to Informal Relationships? Thousand Oaks, CA: Sage.

Baxter, L.A. and Bullis, C. (1986). Turning points in developing romantic relationships. Human Communication Research, 12, pp. 469-493.

Bearman, S., Blake-Beard, S., Hunt, L. and Crosby, F.J. (2007). New directions in mentoring. In Allen, T.D. and Eby, L.T. (eds), Blackwell Handbook of Mentoring: A Multiple Perspectives Approach. New York, NY: Blackwell, pp. 275-295.

Berger, P.L. and Luckmann, T. (1966). The Social Construction of Reality: A Treatise in the Sociology of Knowledge. Garden City, NY: Doubleday.

Berscheid, E. (1999). The greening of relationship science. American Psychologist, 54, pp. 260-266.

Blake-Beard, S.D., O’Neill, R.M. and McGowan, E. (2007). Blind dates? The importance of matching in successful formal mentoring relationships. In Ragins, B.R. and Kram, K.E. (eds), The Handbook of Mentoring at Work: Theory, Research, and Practice. Thousand Oaks, CA: Sage, pp. 617-632.

Blau, P. (1964). Exchange and Power in Social Life. New York, NY: Wiley.

Blickle, G., Schneider, P.B., Meurs, J.A. and Perrewé, P.L. (2010). Antecedents and consequences of perceived barriers to obtaining mentoring: a longitudinal investigation. Journal of Applied Social Psychology, 40, pp. 18971920.

Blickle, G., Witzki, A. and Schneider, P.B. (2009). Selfinitiated mentoring and career success: a predictive field study. Journal of Vocational Behavior, 74, pp. 94-101.

Blustein, D.L. (2011). A relational theory of working. Journal of Vocational Behavior, 79, pp. 1-17.

Blustein, D.L., Schultheiss, D.E.P. and Flum, H. (2004). Toward a relational perspective of the psychology of careers and working: a social constructionist analysis. Journal of Vocational Behavior, 64, pp. 423-440.

Bouquillon, E., Sosik, J. and Lee, D. (2005). 'It's only a phase': examining trust, identification and mentoring func- tions received across the mentoring phases. Mentoring \& Tutoring: Partnership in Learning, 13, pp. 239-258.

Bozeman, B. and Feeney, M.K. (2007). Toward a useful theory of mentoring: a conceptual analysis and critique. $A d$ ministration \& Society, 39, pp. 719-739.

Bozeman, B. and Feeney, M.K. (2008). Mentor matching: a 'Goodness of Fit' model. Administration \& Society, 40, pp. 465-482.

Bozionelos, N. (2004). Mentoring provided: relation to mentor's career success, personality, and mentoring received. Journal of Vocational Behavior, 64, pp. 24-46.

Brummans, B.H.J.M., Cooren, F., Robichaud, D. and Taylor, J.R. (2014). Approaches to the communicative constitution of organizations. In Putnam, L.L. and Mumby, D.K. (eds), The Sage Handbook of Organizational Communication, 3rd edn. Thousand Oaks, CA: Sage, pp. 173-194.

Bryant, S.E. (2005). The impact of peer mentoring on organizational knowledge creation and sharing: an empirical study in a software firm. Group \& Organization Management, 30, pp. 319-338.

Burk, H.G. and Eby, L.T. (2010). What keeps people in mentoring relationships when bad things happen? A field study from the protégé's perspective. Journal of Vocational Behavior, 77, pp. 437-446.

Burke, R.J. and McKeen, C.A. (1997). Benefits of mentoring relationships among managerial and professional women: a cautionary tale. Journal of Vocational Behavior, 51, pp. 43-57.

Burrell, G. and Morgan, G. (1979). Sociological Paradigms and Organisational Analysis: Elements of the Sociology of Corporate Life. London: Heinemann Educational.

Burt, R.S. and Knez, M. (1996). Trust and third-party gossip. In Kramer, R.M. and Tyler, T.R. (eds), Trust in Organizations: Frontiers of Theory and Research. Thousand Oaks, CA: Sage, pp.

Cameron, K., Dutton, J.E. and Quinn, R. (2003). Positive Organizational Scholarship. San Francisco, CA: BerrettKoehler.

Cameron, K.S. and Spreitzer, G.M. (2011). Introduction: what is positive about positive organizational scholarship? In Cameron, K.S. and Spreitzer, G.M. (eds), The Oxford Handbook of Positive Organizational Scholarship. New York, NY: Oxford University Press, pp. 68-89.

Chandler, D.E., Kram, K.E. and Yip, J. (2011). An ecological systems perspective on mentoring at work: a review and future prospects. Academy of Management Annals, 5, pp. 519-570.

Chao, G.T. (1997). Mentoring phases and outcomes. Journal of Vocational Behavior, 51, pp. 15-28.

Chia, R. (1995). From modern to postmodern organizational analysis. Organization Studies, 16, pp. 579-604.

Christensen, L.T. and Cornelissen, J. (2011). Bridging corporate and organizational communication: review, development and a look to the future. Management Communication Quarterly, 25, pp. 383-414. 
Clark, M.S. and Mills, J. (1993). The difference between communal and exchange relationships: what it is and what is not. Personality and Social Psychology Bulletin, 19, pp. 684-691.

Cooren, F., Kuhn, T., Cornelissen, J.P. and Clark, T. (2011). Communication, organizing and organization: an overview and introduction to the special issue. Organization Studies, 32, pp. 1149-1170.

Cotton, R.D., Shen, Y. and Livne-Tarandach, R. (2011). On becoming extraordinary: the content and structure of developmental networks of major league baseball hall of famers. Academy of Management Journal, 54, pp. 15-46.

Cummings, J.N. and Higgins, M.C. (2006). Relational instability at the network core: support dynamics in developmental networks. Social Networks, 28, pp. 38-55.

Cunliffe, A.L. (2008). Orientations to social constructionism: relationally responsive social constructionism and its implications for knowledge and learning. Management Learning, 39, pp. 123-139.

Cunliffe, A.L. and Eriksen, M. (2011). Relational leadership. Human Relations, 64, pp. 1425-1449.

Deci, E.L. and Ryan, R.M. (1985). Intrinsic Motivation and Self-determination in Human Behavior. New York, NY: Plenum Press.

Deci, E.L. and Ryan, R.M. (2000). The 'what' and 'why' of goal pursuits: human needs and the self-determination of behavior. Psychological Inquiry, 11, pp. 227-268.

Deci, E.L. and Ryan, R.M. (2012). Motivation, personality, and development within embedded social contexts: an overview of self-determination theory. In Ryan, R.M. (ed.), Oxford Handbook of Human Motivation. Oxford: Oxford University Press, pp. 85-107.

Deci, E.L., Connell, J.P. and Ryan, R.M. (1989). Selfdetermination in a work organization. Journal of Applied Psychology, 74, pp. 580-590.

Deci, E.L., La Guardia, J.G., Moller, A.C., Scheiner, M.J. and Ryan, R.M. (2006). On the benefits of giving as well as receiving autonomy support: mutuality in close friendships. Personality and Social Psychology Bulletin, 32, pp. 313-327.

DeRue, D.S. and Ashford, S.J. (2010). Who will lead and who will follow? A social process of leadership identity construction in organizations. Academy of Management Review, 35, pp. 627-647.

Dickson, J., Kirkpatrick-Husk, K., Kendall, D., Longabaugh, J., Patel, A. and Scielzo, S. (2014). Untangling protégé self-reports of mentoring functions: further meta-analytic understanding. Journal of Career Development, 41, pp. 263-281.

Dobrow, S.R. and Higgins, M.C. (2005). Developmental networks and professional identity: a longitudinal study. $\mathrm{Ca}$ reer Development International, 10, pp. 567-583.

Dobrow, S.R., Chandler, D.E., Murphy, W.M. and Kram, K.E. (2011). A review of developmental networks: incorporating a mutuality perspective. Journal of Management, pp. 210-242.
Donaldson, S.I., Ensher, E.A. and Grant-Vallone, E.J. (2000). Longitudinal examination of mentoring relationships on organizational commitment and citizenship behavior. Journal of Career Development, 26, pp. 233247.

Durbin, S. and Tomlinson, J. (2014). Female part-time managers: careers, mentors and role models. Gender, Work \& Organization, 21, pp. 308-320.

Eby, L.T. and Allen, T.D. (2008). Moving toward interdisciplinary dialogue in mentoring scholarship: an introduction to the special issue. Journal of Vocational Behavior, 72, pp. 159-167.

Eby, L.T. and McManus, S.E. (2004). The protégé's role in negative mentoring experiences. Journal of Vocational Behavior, 65, pp. 255-275.

Eby, L.T., Allen, T.D., Evans, S.C., Ng, T. and Dubois, D.L. (2008a). Does mentoring matter? A multidisciplinary meta-analysis comparing mentored and non-mentored individuals. Journal of Vocational Behavior, 72, pp. 254 267.

Eby, L.T., Durley, J.R., Evans, S.C. and Ragins, B.R. (2008b). Mentors' perceptions of negative mentoring experiences: scale development and nomological validation. Journal of Applied Psychology, 93, pp. 358-373.

Emerson, R.M. (1976). Social exchange theory. Annual Review of Sociology, 2, pp. 335-362.

Feldman, D.C. (1999). Toxic mentors or toxic protégés? A critical re-examination of dysfunctional mentoring. $\mathrm{Hu}$ man Resource Management Review, 9, pp. 247-278.

Felmee, D.H. (2001). No couple is an island: a social network perspective on dyadic stability. Social Forces, 79, pp. 1259-1287.

Ferrin, D.L., Dirks, K.T. and Shah, P.P. (2006). Direct and indirect effects of third-party relationships on interpersonal trust. Journal of Applied Psychology, 91, pp. 870883.

Flanagan, J.C. (1954). The critical incident technique. Psychological Bulletin, 51, pp. 327-358.

Fletcher, J.K. (1996). A relational approach to developing the protean worker. In Hall, D.T. (ed.), The Career Is DeadLong Live the Career: A Relational Approach to Careers. San Francisco, CA: Jossey-Bass, pp. 105-131.

Fletcher, J.K. and Ragins, B.R. (2007). Stone center relational cultural theory: a window on relational mentoring. In Ragins, B.R. and Kram, K.E. (eds), The Handbook of Mentoring at Work: Theory, Research, and Practice. Thousand Oaks, CA: Sage, pp. 373-399.

Flum, H. (2001). Relational dimensions in career development. Journal of Vocational Behavior, 59, pp. 1-16.

George, J.M. and Jones, G.R. (2000). The role of time in theory and theory building. Journal of Management, 26, pp. 657-684.

Ghosh, R. (2014). Antecedents of mentoring support: a metaanalysis of individual, relational, and structural or organizational factors. Journal of Vocational Behavior, 84, pp. 367-384. 
Ghosh, R. and Reio Jr., T.G. (2013). Career benefits associated with mentoring for mentors: a meta-analysis. Journal of Vocational Behavior, 83, pp. 106-116.

Godshalk, V.M. and Sosik, J.J. (2000). Does mentor-protégé agreement on mentor leadership behavior influence the quality of a mentoring relationship? Group \& Organization Management, 25, pp. 291-317.

Godshalk, V.M. and Sosik, J.J. (2003). Aiming for career success: the role of learning goal orientation in mentoring relationships. Journal of Vocational Behavior, 63, pp. 417437.

Haggard, D.L., Dougherty, T.W., Turban, D.B. and Wilbanks, J.E. (2011). Who is a mentor? A review of evolving definitions and implications for research. Journal of Management, 37, pp. 280-304.

Hall, D.T. (1996). Protean careers of the $21 \mathrm{st}$ century. Academy of Management Executive, 10, pp. 8-16.

Hall, D.T. and Chandler, D.E. (2007). Career cycles and mentoring. In Kram, K.E. and Ragins, B.R. (eds), The Handbook of Mentoring at Work: Theory, Research, and Practice. Thousand Oaks, CA: Sage, pp. 471-498.

Hartmann, N.N., Rutherford, B.N., Feinberg, R. and Anderson, J.G. (2014). Antecedents of mentoring: do multifaceted job satisfaction and affective organizational commitment matter? Journal of Business Research, 67, pp. 2039-2044.

Hernes, T. and Weik, E. (2007). Organization as process: drawing a line between endogenous and exogenous views. Scandinavian Journal of Management, 23, pp. 251-264.

Higgins, M.C. (2000). The more the merrier? Multiple developmental relationships and work satisfaction. Journal of Management Development, 19, pp. 277-296.

Higgins, M.C. (2001). Changing careers: the effects of social context. Journal of Organizational Behavior, 22, pp. 595618.

Higgins, M.C., Dobrow, S.R. and Roloff, K.S. (2010). Optimism and the boundaryless career: the role of developmental relationships. Journal of Organizational Behavior, 31, pp. 749-769.

Higgins, M.C. and Kram, K.E. (2001). Reconceptualizing mentoring at work: a developmental network perspective. Academy of Management Review, 26, pp. 264-288.

Higgins, M.C. and Thomas, D.A. (2001). Constellations and careers: toward understanding the effects of multiple developmental relationship. Journal of Organizational Behavior, 22, pp. 237-247.

Horvath, M., Wasko, L.E. and Bradley, J.L. (2008). The effect of formal mentoring program characteristics on organizational attraction. Human Resource Development Quarterly, 19, pp. 323-349.

Hu, C., Baranik, L.E. and Wu, T. (2014). Antidotes to dissimilar mentor-protégé dyads. Journal of Vocational Behavior, 85, pp. 219-227.

$\mathrm{Hu}, \mathrm{C}$., Thomas, K.M. and Lance, C.E. (2008). Intentions to initiate mentoring relationships: Understanding the impact of race, proactivity, feelings of deprivation, and re- lationship roles. Journal of Social Psychology, 148, pp. 727-744.

Kao, K., Rogers, A., Spitzmueller, C., Lin, M. and Lin, C. (2014). Who should serve as my mentor? The effects of mentor's gender and supervisory status on resilience in mentoring relationships. Journal of Vocational Behavior, 85, pp. 191-203.

Kram, K.E. and Ragins, B.R. (2007). The landscape of mentoring in the 21 st century. In Ragins, B.R. and Kram, K.E. (eds), The Handbook of Mentoring at Work: Theory, Research, and Practice. Thousand Oaks, CA: Sage, pp. 659692.

Janssen, S., van Vuuren, M. and de Jong, M.D.T. (2013). Identifying support functions in developmental relationships: a self-determination perspective. Journal of Vocational Behavior, 82, pp. 20-29.

Janssen, S., van Vuuren, M. and de Jong, M.D.T. (2014). Motives to mentor: self-focused, protégé-focused, relationship-focused, organization-focused, and unfocused motives. Journal of Vocational Behavior, 85, pp. 266275.

Jones, R. and Corner, J. (2012). Seeing the forest and the trees: a complex adaptive systems lens for mentoring. $\mathrm{Hu}$ man Relations, 65, pp. 391-411.

Jordan, J., Kaplan, A., Miller, J.B., Stiver, I. and Surrey, J. (1991). Women's Growth-in-Connection. New York, NY: Guilford Press.

Kirchmeyer, C. (2005). The effects of mentoring on academic careers over time: testing performance and political perspectives. Human Relations, 58, pp. 637-660.

Kram, K.E. (1983). Phases of the mentoring relationship. Academy of Management Journal, 26, pp. 608-625.

Kram, K.E. (1985). Mentoring at Work: Developmental Relationships in Organizational Life. Glenview, IL: Scott Foresman.

Kram, K.E. and Isabella, L. (1985). Mentoring alternatives: the role of peer relationships in career development. Academy of Management Journal, 28, pp. 110132.

Langley, A. and Tsoukas, H. (2010). Introducing perspectives on process organization studies. In Hernes, T. and Maitlis, S. (eds), Process, Sensemaking, and Organizing: Perspectives on Process Organization Studies. Oxford: Oxford University Press, pp. 1-26.

Lankau, M.J., Riordan, C.M. and Thomas, C.H. (2005). The effects of similarity and liking in formal relationships between mentors and protégés. Journal of Vocational Behavior, 67, pp. 252-265.

Maguire, M.C. (1999). Treating the dyad as the unit of analysis: a primer on three analytic approaches. Journal of Marriage and Family, 61, pp. 213-223.

McKeen, C. and Bujaki, M. (2007). Gender and mentoring: issues, effects, and opportunities. In Ragins, B.R. and Kram, K.E. (eds), The Handbook of Mentoring at Work: Theory, Research, and Practice. Thousand Oaks, CA: Sage, pp. 197-222. 
Mezias, J.M. and Scandura, T.A. (2005). A needs-driven approach to expatriate adjustment and career development: a multiple mentoring perspective. Journal of International Business Studies, 36, pp. 519-538.

Miller, J.B. (1976). Toward a New Psychology of Women. Boston, MA: Beacon Press.

Missirian, A.K. (1982). The Corporate Connection: Why Executive Women Need Mentors to Reach the Top. Englewood Cliffs, NJ: Prentice-Hall.

Murphy, W.M. and Kram, K.E. (2010). Understanding nonwork relationships in developmental networks. Career Development International, 15, pp. 637-663.

Noe, R.A. (1988). An investigation of the determinants of successful assigned mentoring relationships. Personnel Psychology, 41, pp. 457-479.

Noe, R.A., Greenberger, D.B. and Wang, S. (2002). Mentoring: what we know and where we might go. Research in Personnel and Human Resource Management, 21, pp. 129-173.

Olian, J.D., Carroll, S.J. and Giannantonio, C.M. (1993). Mentor reactions to protégés: an experiment with managers. Journal of Vocational Behavior, 43, pp. 266-278.

Olian, J.D., Carroll, S.J., Giannantonio, C.M. and Feren, D.B. (1988). What do protégés look for in a mentor? Results of three experimental studies. Journal of Vocational Behavior, 33, pp. 15-37.

Pan, W., Sun, L.-Y. and Chow, I.H.S. (2011). The impact of supervisory mentoring on personal learning and career outcomes: the dual moderating effect of self-efficacy. Journal of Vocational Behavior, 78, pp. 264-273.

Payne, S.C. and Huffman, A.H. (2005). A longitudinal examination of the influence of mentoring on organizational commitment and turnover. Academy of Management Journal, 48, pp. 158-168.

Phillips, L.L. (1977). Mentors and Protégés: A Study of the Career Development of Women Managers and Executives in Business and Industry. Los Angeles, CA: University of California.

Planalp, S. (1985). Relational schemata: a test of alternative forms of relational knowledge as guides to communication. Human Communication Research, 12, pp. 3-29.

Planalp, S. (1987). Interplay between relational knowledge and events. In Burnett, R., McGhee, P. and Clarke, D. (eds), Accounting for Relationships: Explanation, Representation, and Knowledge. New York, NY: Methuen, pp. 175-191.

Pollock, R. (1995). A test of conceptual models depicting the developmental course of informal mentor-protégé relationships in the work place. Journal of Vocational Behavior, 46, pp. 144-162.

Pratt, M. (2012). Rethinking identity construction processes in organizations: three questions to consider. In Schultz, M., Maguire, S., Langley, A. and Tsoukas, H. (eds), Constructing Identity in and around Organizations. Oxford: Oxford University Press, pp. 21-49.
Raabe, B. and Beehr, T.A. (2003). Formal mentoring versus supervisor and coworker relationships: differences in perceptions and impact. Journal of Organizational Behavior, 24, pp. 271-293.

Ragins, B.R. (2012). Relational mentoring: a positive approach to mentoring at work. In Cameron, K.S. and Spreitzer, G.M. (eds), The Oxford Handbook of Positive Organizational Scholarship. New York, NY: Oxford University Press, pp. 519-536.

Ragins, B.R. and Cotton, J.L. (1993). Gender and willingness to mentor in organizations. Journal of Management, 19, pp. 97-111.

Ragins, B.R. and Cotton, J.L. (1999). Mentor functions and outcomes: a comparison of men and women in formal and informal mentoring relationships. Journal of Applied Psychology, 4, pp. 529-550.

Ragins, B.R. and Kram, K.E. (2007). The roots and meaning of mentoring. In Ragins, B.R. and Kram, K.E. (eds), The Handbook of Mentoring at Work: Theory, Research, and Practice. Thousand Oaks, CA: Sage, pp. 3-15.

Ragins, B.R. and McFarlin, D.B. (1990). Perceptions of mentor roles in cross-gender mentoring relationships. Journal of Vocational Behavior, 37, pp. 321-339.

Ragins, B.R. and Scandura, T.A. (1997). The way we were: gender and the termination of mentoring relationships. Journal of Applied Psychology, 82, pp. 945-953.

Ragins, B.R. and Scandura, T.A. (1999). Burden or blessing? Expected costs and benefits of being a mentor. Journal of Organizational Behavior, 20, pp. 493-509.

Ragins, B.R. and Verbos, A.K. (2007). Positive relationships in action: relational mentoring and mentoring schemas in the workplace. In Dutton, J.E. and Ragins, B.R. (eds), Positive Relationships at Work: Building a Theoretical and Research Foundation. Mahwah, NJ: Lawrence Erlbaum, pp. 91-116.

Ramaswami, A., Huang, J.C. and Dreher, G.F. (2014). Mentoring across cultures: the role of gender and marital status in Taiwan and the U.S. Journal of Business Research, 67, pp. 2542-2549.

Rescher, N. (1996). Process Metaphysics: an Introduction to Process Philosophy. New York, NY: SUNY.

Rohatinsky, N. (2014). Mentorship in healthcare organizations: managers' perspectives. Management Education, 13, 11-20.

Russell, J.E.A. and Adams, D.M. (1997). The changing nature of mentoring in organizations: an introduction to the special issue on mentoring in organizations. Journal of Vocational Behavior, 51, pp. 1-14.

Ryan, R.M., Patrick, H., Deci, E.L. and Williams, G.C. (2008). Facilitating health behaviour change and its maintenance: interventions based on self-determination theory. European Health Psychologist, 10, pp. 2-5.

Scandura, T.A. (1997). Mentoring and organizational justice: an empirical investigation. Journal of Vocational Behavior, 51, pp. 58-69. 
Scandura, T.A. and Ragins, B.R. (1993). The effects of sex and gender role orientation on mentorship in maledominated occupations. Journal of Vocational Behavior, 43, pp. 251-265.

Singh, R., Ragins, B.R. and Tharenou, P. (2009). Who gets a mentor? A longitudinal assessment of the rising star hypothesis. Journal of Vocational Behavior, 74, pp. 1117.

Sminia, H. (2009). Process research in strategy formation: theory, methodology and relevance. International Journal of Management Reviews, 11, pp. 97-125.

Stone, D.N., Deci, E.L. and Ryan, R.M. (2009). Beyond talk: creating autonomous motivation through selfdetermination theory. Journal of General Management, 34, pp. 75-91.

Sun, L., Pan, W. and Chow, I.H.S. (2014). The role of supervisor political skill in mentoring: dual motivational perspectives. Journal of Organizational Behavior, 35, pp. 213233.

Tsoukas, H. and Chia, R. (2002). On organizational becoming: rethinking organizational change. Organization Science, 13, pp. 567-582.

Uhl-Bien, M. (2006). Relational leadership theory: exploring the social processes of leadership and organizing. Leadership Quarterly, 17, pp. 654-676.

Underhill, C.M. (2006). The effectiveness of mentoring programs in corporate settings: a meta-analytical review of the literature. Journal of Vocational Behavior, 68, pp. 292307.

Van de Ven, A.H. and Poole, M.S. (2005). Alternative approaches for studying organizational change. Organization Studies, 26, pp. 1377-1404.

Van Emmerik, I.J.H. (2004). The more you can get, the better: mentoring constellations and intrinsic career success. Career Development International, 9, pp. 578594.

Van Emmerik, I.J.H., Baugh, S.G. and Euwema, M.C. (2005). Who wants to be a mentor? An examination of attitudinal, instrumental, and social motivational components. Career Development International, 10, pp. 310-324.

Vansteenkiste, M., Simons, J., Lens, W., Sheldon, K.M. and
Deci, E.L. (2004). Motivating learning, performance, and persistence: the synergistic role of intrinsic goals and autonomy-support. Journal of Personality and Social Psychology, 87, pp. 246-260.

Verbrugge, L.M. (1979). Multiplexity in adult friendships. Social Forces, 57, pp. 1286-1309.

Wanberg, C.R., Welsh, E.T. and Hezlett, S.A. (2003). Mentoring research: a review and dynamic process model. $R e-$ search in Personnel and Human Resource Management, 22, pp. 39-124.

Wang, S., Noe, R.A., Wang, Z. and Greenberger, D.B. (2009). What affects willingness to mentor in the future? An investigation of attachment styles and mentoring experiences. Journal of Vocational Behavior, 74, pp. 245-256.

Waters, L. (2004). Protégé-mentor agreement about the provision of psychosocial support: the mentoring relationship, personality, and workload. Journal of Vocational Behavior, 65, pp. 519-532.

Weick, K.E. (1995). Sensemaking in Organizations. Thousand Oaks, CA: Sage.

Weick, K.E., Sutcliffe, K.M. and Obstfeld, D. (2005). Organizing and the process of sensemaking. Organization Science, 16, pp. 409-421.

Weik, E. (2011). In deep waters: process theory between Scylla and Charybdis. Organization, 18, pp. 655-672.

Welch, C. and Paavilainen-Mäntymäki, E. (2014). Putting process (back) in: research on internationalization process of the firm. International Journal of Management Reviews, 16, pp. 2-23.

Whetten, D.A. (1989). What constitutes a theoretical contribution? Academy of Management Review, 14, pp. 490495.

Young, A.M., Cady, S. and Foxon, M.J. (2006). Demystifying gender differences in mentoring: theoretical perspectives and challenges for future research on gender and mentoring. Human Resource Development Review, 5, pp. 148-175.

Young, A.M. and Perrewé, P.L. (2000). The exchange relationship between mentors and protégés: the development of a framework. Human Resource Development Review, 10, pp. 177-209. 